\title{
ANALISA PERBANDINGAN METODE CERTAINTY FACTOR DENGAN DEMPSTER SHAFER PADA SISTEM PAKAR UNTUK MENDIAGNOSIS PENYAKIT BALITA USIA KURANG DARI 5 TAHUN
}

\author{
Moh. Teguh Kalimatullah ${ }^{1}$, Suryo Adi Wibowo ${ }^{2}$, Karina Auliasari ${ }^{3}$ \\ Program Studi Teknik Informatika S1, Fakultas Teknologi Industri \\ Institut Teknologi Nasional Malang, Jalan Raya Karanglo km 2 Malang, Indonesia \\ moh.teguhkalimatullah@gmai.com
}

\begin{abstract}
ABSTRAK
Kebanyakan masyarakat yang ada dipedesaan masih sering salah menyimpulkan penyakit dan gejala yang dialami buah hatinya, biasanya pernyakit tersebut dibilang penyakit biasa saja, dikarenakan gejala awalnya hanyalah balita itu terlihat letih, gelisah dan berkeringat banyak. Sehingga terlambat dalam penanganan oleh pihak medis. Banyaknya jenis-jenis penyakit baru saat ini yang diderita balita dan kurang cepatnya penyebaran informasi penyakit kepada masyarakat, menyebabkan dinas Kesehatan memikirkan solusi bagaimana caranya agar sosialisasi penyakit dari gejala sampai cara penanganan pertamanya dapat disebarluaskan secara menyeluruh kepada masyarakat luas.

Maka dari itu dibuatlah sistem pakar untuk membantu masyarakat dalam mengurangi masalah penyakit dan gejala pada balita. Pada penelitian kali ini, sistem pakar yang dibuat untuk membandingkan metode Certainty Factor dengan Demster shafer bertujuan untuk mendefinisikan ukuran kepastian pada penyakit balita terhadap fakta atau aturan dari gejala yang dialami balita yang sedang sakit. Dan juga untuk memberikan nilai kepastian dari hasil metode, dengan adanya sistem pakar ini, diharapkan dapat membantu para pengguna atau masyarakat dalam mendiagnosis penyakit pada balita yang dialami.

Hasil Pengujian Analisa Perbandingan Metode Certainty Factor dengan Demster Shafer Pada Sistem Pakar Untuk Mendiagnosis Penyakit Balita Usia Kurang dari 5 Tahun dapat disimpulakan bahwa pada metode Certainty Factor hasil fungsional berjalan dengan baik dengan persentase eror sebanyak 0,150605\% yang telah diuji dari perhitungan excel dan sistem yang telah dibuat, pada metode Demster Shafer hasil fungsional berjalan dengan baik dengan persentase eror sebanyak 0\% didapat dari hasil perhitungan excel dengan sistem yang telah di buat. Setelah melakukkan konsultasi terhadap dokter, bahwa motede yang mendekati hasil yang sama yaitu pada metode Demster Shafer.
\end{abstract}

Kata kunci : Sistem Pakar, Certainty Factor, Demster shafer, Penyakit pada balita

\section{PENDAHULUAN}

\subsection{Latar Belakang}

Program Imunisasi di Indonesia di pengaruhi oleh peran dan pengetahuan ibu. Pengetahuan ibu tentang imunisasi dipengaruhi oleh berbagai faktor diantaranya pendidikan, informasi, social budaya,/ekonomi, lingkungan, pengalaman dan usia. Dimana tingkat pengetahuan ibu dipengaruhi oleh kepatuhan dalam pemberian imunisasi dasar lengkap pada anak usia balita, sehingga dapat mempengaruhi status imunisasi pada balita. Salah satu upaya pencegahan penyakit pada balita adalah melalui upaya pengebalan (imunisasi). Tujuan utama imunisasi untuk menurunkan angka kesakitan dan kematian karena berbagai penyakit yang dapat dicegah dengan imunisasi. Imunisasi adalah pemberian vaksin untuk mencegah terjadinya penyakit tertentu.

Sistem pakar adalah program kecerdasan buatan yang mengabungkan pangkalan pengetahuan manusia ke komputer, agar komputer dapat menyelesaikan masalah seperti yang biasa dilakukan para ahli.diharapkan dari pakar ini, pengguna dapat menyelsaikan masalah dengan sistem pakar tersebut dengan melakukan mempresentasikan dan melakukan penalaran dengan pengetahuan dari seorang pakar untuk memecahkan masalah atau memberikan saran kepada yang mempunyai masalah.

Sistem pakar tersebut nantinya dapat mempermudah dokter bayi, balita, anak atau para ahli kesehatan pada usia balita untuk mempelajari tentang gejala dan penyakit yang menjadi permasalahan dengan cara mendiagnosis gejala. Tujuannya adalah untuk membantu dan mencegah terjadinya lebihnparahnya penyakit yang di derita pada anak balita.

Maka dari itu untuk membuat sistem pakar saya membandingkan metode Certainty Factor dengan metode Demster shafer. Alasan saya membandingkan metode Certainty Factor dengan metode Demster shafer adalah untuk membandingkan metode Certainty Factor dengan metode Demster shafer manakah yang lebih maksimal yang dilihat dari hasil penelitian. 


\subsection{Rumusan Masalah}

Berdasarkan latar belakang yang telah dikemukakan di atas, maka dapat dibuat sebuah rumusan masalah yaitu "Bagaimana mengembangkan sistem dengan cara Menganalisa Perbandingan Metode Certainty Factor dengan Demster Shafer Pada Sistem Pakat Untuk Mendiagnosis Penyakit Balita Usia Kurang dari 5 Tahun, dan untuk mencari nilai keakuratan diantara kedua metode melalui konsultasi pakar atau dokter balita".

\subsection{Tujuan} adalah :

Adapun tujuan dari pengembangan aplikasi ini

1. Untuk menggetahui penyakit yang sedang pada balita usaia kurang dari 5 tahun.

2. Untuk mengembangkan sistem pakar yang digunakan untuk mengetahui penyakit pada balita dibawah umur dari 5 tahun.

3. Sistem dibuat untuk membantu dokter spesialis balita dan Puskesmas.

4. Untuk mengembangkan system pakar pada perbandingkan metode Certainty Factor dengan Demster Shafer dan untuk mengetahui hasil penyakit yang diderita balita usia kurang dari 5 tahun.

\section{TINJAUAN PUSTAKA}

\subsection{Penelitian Terkait}

Di tahun 2015 Putra dan Rahmad dkk menganalisis perbandingan metode Certainty Factor dan Demster Shafer pada sistem pakar diagnosa penyakit diabetes melitus. Tujuan dari menganalisis metode tersebut untuk mengakomodasi ketidakpastian pemikiran seorang pakar dengan nilai kepastian, sedangkan dempster shafer merupakan teori pembuktian matematika berdasarkan nilai belief dan plausability. Untuk membandingkan keduanya, dibuatlah suatu prototipe sistem pakar dengan basis pengetahuan dengan 100 sampel data pasien yang sama. Dari hasil analisa statistik, kesimpulannya, ada perbedaan hasil diagnosa antara kedua metode dan metode dempster shafer lebih tepat digunakan pada sistem pakar diagnosa penyakit diabetes melitus.[1]

Dua tahun setelah Putra dan Rahmad menganalisis 2 metode Certainty Factor dan Demster Shafer, Hamidi dkk juga melakukan analisis pada sistem pakar dengan membandingkan metode Certainty Factor dengan metode Demster Shafer pada penyakit kelinci. Tujuan dalam penelitian tersebut, penulis menganalisis perbandingan hasil diagnosis pada system pakar penyakit kelinci dengan menggunakan metode Certainty Factor dan metode Dempster Shafer membandingkan kesesuaian dari hasil diagnosis antara system dengan hasil diagnosis pakar sehingga dapat diketahui metode manakah di antara kedua metode tersebut yang lebih baik. Berdasarkan hasil pengujian tingkat keakuratan, didapat hasil bahwa hasil nilai keakuratan metode Certainty Factor adalah $80 \%$, sedangkan hasil nilai keakuratan metode Dempster Shafer adalah $85 \%$, dapat ditarik kesimpulan bahwa metode Dempster Shafer keakuratan nilainya lebih baik dibanding metode Certainty Factor dalam mendiagnosis penyakit kelinci.[2]

Ditahun yang sama setelah Hamidi dkk, Putra melakukkan diagnosis pada penyakit ISPA (Infeksi Saluran Pernafasan Akut) menggunakan metode Certainty Factor berbasis web. Dari hasil pengujian yang diakukkan pada metode baik melalui simulasi program, perhitungan manual menyatakan bahwa hasil dari perhitungan memiliki nilai prosentase error yang dihasilkan $0.0273 \%$. Hasil pengujian fungsional dari sistem dengan akses sebagai admin dan user berjalan sesuai fungsinya pada browser. Pada tahap pengujian aplikasi yang dilakukan dengan menggunakan 2 browser yaitu Google Chrome 54.0 dan Mozilla Firefox 50.0.2 semua fungsi dari system berjalan sesuai dengan yang diinginkan.Pada pengujian sistem yang dilakukan untuk menguji keakuratan perhitungan system dan anlisis perhtungan didapatkan nilai prosentase error tertinggi $0,095 \%$,error terendah $0.0026 \%$ dan rata-rata eror sebesar $0,0273 \%$.[3]

Di tahun 2017 M. Yusuf membuat sistem pakar diagnosis penyakit Leukemia menggunakan Demster Shafer berbasis android. Dari hasil sistem pakar tersebut mendapatkan Nilai keyakinan paling kuat adalah terhadap penyakit $\{$ LLK $\}$ yaitu sebesar 0.60 , yang didapatkan dari dua gejala yang ada yaitu G01 dan G02. faktor selanjutnya yaitu Nyeri tulang dan atau sendi Kemudian apabila diketahui adanya fakta baru, yaitu adanya faktor Tekanan Darah Normal (G04), setelah melakukan perhitungan Nilai keyakinan yang didapatkan paling kuat adalah terhadap penyakit $\{$ LLK $\}$ yaitu sebesar 0.4399 , yang didapatkan dari tiga gejala yang ada yaitu G02, G03 dan G04.[4]

Setahun sebelum M. Yusuf membuat sistem pakar diagnosis penyakit Leukemia menggunakan Demster Shafer berbasis android, Orisa membuat aplikasi sistem pakar diagnosis penyakit tebu menggunakan metode Certainty Factor berbasis web. Penyebab orisa melakukan diagnosis pada penyakit tebu adalah kurangnya penyebaran pengetahuan penyakit dikalangan petani, menyebabkan diperlukannya sistem pakar untuk diagnosis penyakit. Sistem pakar diagnosis penyakit tanaman tebu dibangun dengan bahasa pemrograman web PHP dan database MySQL. Representasi pengetahuan menggunakan kaidah produksi, proses inferensi menggunakan forward chaining dan proses perhitungan nilai kepastian terjadinya penyakit dilakukan menggunakan metode certainty factor. Para petani dapat mendiagnosis penyakit yang terjadi pada tanaman tebu dan mengetahui cara penanganan 
penyakit dengan menjawab pertanyaan-pertanyaan yang diajukan sistem. [5]

\subsection{Certainty Factor}

Teori Certainty Factor (CF) adalah untuk menyelesaikan masalah kepastian dan ketidakpastian. Metode certainty factor atau CF merupakan nilai untuk mengukur keyakinan pakar. CF diperkenalkan oleh Shortliffe Buchanan dalam pembuatan sistem pakar MYCIN yang merupakan nilai parameter klinis yang di berikan MYCIN untuk menunjukkan besarnya kepercayaan. CF menunjukkan ukuran kepastian terhadap suatu fakta atau aturan. Nilai tertinggi dari $\mathrm{CF}$ adalah $+1,0$ (pasti benar atau definitely), dan nilai terendah dalam CF adalah $-1,0$ (pasti salah atau definitely not). Nilai positif merepresentasikan derajat keyakinan, sedangkan nilai negatif merepresentasikan derajat ketidakyakinan. Definisi Certainty Factor sebagai berikut :

Keterangan :

$$
\mathrm{CF}[\mathrm{h}, \mathrm{e}]=\mathrm{MB}[\mathrm{h}, \mathrm{e}]-\mathrm{MD}[\mathrm{h}, \mathrm{e}]
$$

$\mathrm{CF}$ [h,e] : Faktor kepastian

$\mathrm{MB}[\mathrm{h}, \mathrm{e}]$ : Ukuran kepercayaan atau tingkat keyakinan terhadap hipotesis $\mathrm{h}$, jika diberikan evidence e (antara 0-1).

$\mathrm{MD}[\mathrm{h}, \mathrm{e}]$ : Ukuran kepercayaan atau tingkat keyakinan terhadap hipotesis h, jika diberikan evidence e (antara 0-1).[6]

\subsection{Demster Shafer}

Teori Dempster Shafer pertama kali diperkenalkan oleh Arthur P. Dempster, yang melakukan percobaan model ketidakpastian dengan range probabilities daripada sebagai probabilitas tunggal. Kemudian pada tahun 1976 Glenn Shafer mempublikasikan teori Dempster tersebut pada sebuah buku yang berjudul Mathematical Theory of Evident. Dempster Shafer adalah teori matematika untuk pembuktian berdasarkan belief functions dan plausible reasoning (fungsi kepercayaan dan pemikiran yang masuk akal), yang digunakan untuk mengkombinasikan potongan informasi yang terpisah (bukti) untuk mengkalkulasi kemungkinan dari suatu peristiwa. Teori ini mampu menunjukkan suatu cara memberikan bobot keyakinan sesuai fakta yang dikumpulkan. Pada teori ini dapat membedakan ketidakpastian dan ketidaktahuan. Teori ini memiliki beberapa karakteristik yang secara intuitif sesuai dengan cara berpikir seorang pakar, namun dengan dasar matematika yang kuat [7].

\subsection{Sistem Pakar}

Sisem pakar merupakan sebuah sistem yang kinerjnya untuk mengadopsi keahlian yang dimiliki pakar atau bidang tertentu ke dalam sistem atau program ke dalam komputer yang di sajikan dengan tampilan yang dapat digunakan oleh pengguna atau user, sehingga dengan sistem tersebut pengguna atau user dapat membuat sebuah keputusan dan menentukan kebijakan layaknya seorang pakar. Konsep dasar pada sistem pakar dapat dilihat pada gambar 2.1.

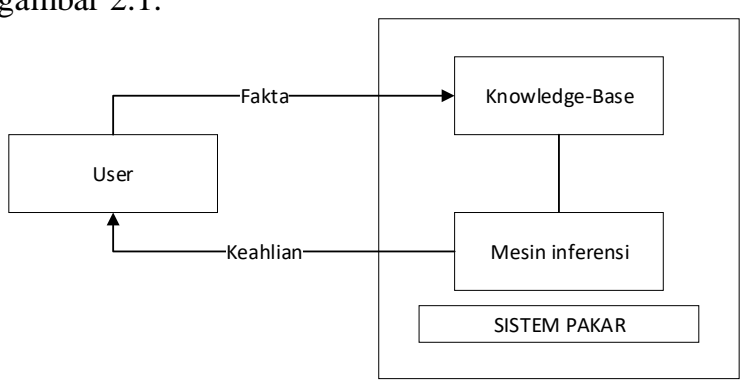

Gambar 2.1 Konsep dasar pada sistem pakar

Konsep dasar dari sistem pakar tersebut, user atau pengguna menyampaikan fakta atau informasi kedalam sistem pakar, selanjutnya fakta dan informasi tersebut di simpan ke dalam knowledgebase dan di olah ke mesin inferensi, sehingga sistem akan memberikan timbal balik kepada user mengenai informasi keahlian atau jawaban berdasarkan pengetahuan yang sudah ada di dalam sistem tersebut. [8].

\subsection{Penyakit Balita}

Penyakit balita masih merupakan masalah kesehatan yang penting karena menyebabkan kematian bayi dan balita yang cukup tinggi yaitu kirakira 1 dari 4 kematian yang terjadi pada anak. Setiap anak diperkirakan mengalami 3-6 episode ISPA setiap tahunnya. $40 \%-60 \%$ dari kunjungan di Puskesmas adalah penyakit ISPA.[9] Puskesmas merupakan organisasi fungsional yang menyelenggarakan upaya kesehatan yang bersifat menyeluruh, terpadu, merata, dapat dijangkau dan diterima oleh masyarakat, dengan biaya yang dapat dipikul oleh pemerintah dan juga masyarakat. Upaya kesehatan tersebut diselenggarakan dengan menitikberatkan kepada pelayanan untuk masyarakat luas guna mencapai derajad kesehatan yang optimal bagi masyarakat, tanpa mengabaikan mutu pelayanan kepada perorangan yang telah di bahas di Undangundang Nomor 40 Tahun 2004 tentang Sistem Jaminan Sosial Nasional, maka disini Puskesmas menjadi suatu bagian layanan kesehatan yang paling mendasar, dikarenakan [10] Puskesmas memberikan pelayanan kesehatan bagi masyarakat dan pelayaan pertama di tingkat kecamatan dan menangani pasien dari beberapa desa, dikarekanan banyaknya jenis penyakit yang berbeda-beda, maka di sebutkan pelayaan yang pertama untuk masyarakat.[11] Kebayakan Penyebab masyarakat salah menyimpulkan gejala penyakit yang dialami hanya gejala yang sederhana, dikarenakan gejala yang berbeda-beda, dan awalnya hanya balita itu terlihat letih, sehingga terlambat dalam penanganan oleh pihak medis. 


\subsection{Website}

Website adalah sekumpulan halaman yang menampilkan informasi data, teks, gambar diam atau bergerak, animasi, video ataupun gabungan dari semua itu. Baik yang bersifat statis maupun dinamis, bersifat statis apabila isi dari website tersebut tetap dan isi kontennya dari pemilik website, bersifat dinamis apabila isi dan informasi yang ada di website tersebut berubah ubah dan selalu update contohnya adalah facebook dan twitter, dalam pengembangan website tersebut website statis hanya bias di update pemilik website tersebut, sedangkan website dinamis bias di update pemilik maupun pengguna website tersebut.[12]

\subsection{PHP}

PHP adalah salah satu bahasa pemrograman scrip yang dirancang untuk membangun aplikasi web. Ketika dipanggil dari web browser, program yang ditulis dengan PHP akan di-parsing di dalam web server oleh interpreter PHP dan diterjemahkan ke dalam dokumen HTML, yang selanjutnya akan ditampilkan kembali ke web browser. Kerena pemrosesan program PHP dilakukan di lingkungan web server, PHP dikatakan sebagai bahasa sisi server (server-side). Oleh sebab itu, seperti yang telah dikemukakan sebelumnya, kode PHP tidak akan terlihat pada saat user memilih perintah "View Source" pada web browser yang digunakan.[13]

\subsection{CSS}

Cascading Style Sheet (css), merupakan kepanjangan dari CSS. Penggunaan CSS membuat pemrograman Web menjadi lebih mudah karena kita dapat melakukan penyeragaman format terhadap elemen-elemen yang sama dalam situs dengan cepat. Saat ini hampir semua situs berbasis HTML menggunakan CSS untuk meningkatkan keluwesan tampilan. CSS dapat disimpan dalam file terpisah dengan ekstensi .css, dan setiap perubahan yang dilakukan pada file tersebut akan mempengaruhi seluruh dokumen HTML yang terkait padanya. Dengan demikian, waktu untuk melakukan perubahan terhadap situs dengan jumlah halaman yang banyak dapat dikurangi berkat bantuan CSS.[14]

\subsection{Database MySQL}

Basis data merupakan kumpulan data dari berbagai sumber yang saling berhubungan dan disimpan secara bersama dalam media penyimpanan elektronis tanpa adanya pengulangan (redudansi).

Pengertian MySQL menurut MySQL manual adalah sebuah open source software database SQL (Search Query Language) yang menangani sistem manajemen database dan sistem manajemen database relational. MySQL adalah open source software yang dibuat oleh sebuah perusahaan Swedia yaitu MySQLAB. MySQL sangat mudah digunakan, reliable dan sangat cepat.[15]

\section{METODE PENELITIAN 3.1. Data penyakit}

\begin{tabular}{|c|l|}
\multicolumn{2}{|c|}{ Table 3.1 Data Penyakit } \\
\hline Kode Penyakit & \multicolumn{1}{|c|}{ Nama Penyakit } \\
\hline P0001 & $\begin{array}{l}\text { Demam Typhoid dan Paratyphoid (Panas } \\
\text { tipes) }\end{array}$ \\
\hline P0002 & Diare Dan Gastroenteritis \\
\hline P0003 & Marasmus Gizi \\
\hline P0004 & Konjungtivitis \\
\hline P0005 & Common Cold (batuk, panas) \\
\hline P0006 & Infeksi Akut Saluran Pernafasan Atas \\
\hline P0007 & Asma \\
\hline P0008 & Gastritis, unspecified \\
\hline P0009 & Penyakit Kulit Alergi \\
\hline P0010 & Penyakit Kulit Infeksi \\
\hline P0011 & Kejang \\
\hline P0012 & Disentri / Shigellosis \\
\hline P0013 & Demam Dengue / Suspect \\
\hline P0014 & Herpes Simplex \\
\hline P0015 & Cacar Air \\
\hline P0016 & Campak tanpa komplikasi \\
\hline
\end{tabular}

\subsection{Data Gejala}

Table 3.2 Data Gejala

\begin{tabular}{|l|l|}
\hline $\begin{array}{c}\text { Kode } \\
\text { Gejala }\end{array}$ & \\
\hline G0001 & Demam tinggi \\
\hline G0002 & Diare \\
\hline G0003 & Terlihat lemah atau lemas \\
\hline G0004 & Sembelit \\
\hline G0005 & Kehilangan nafsu makan \\
\hline G0006 & Fases cair \\
\hline G0007 & Mual muntah \\
\hline G0008 & Sakit Perut \\
\hline G0009 & Demam \\
\hline G0010 & Tampak sangat kurus \\
\hline G0011 & Rewel \\
\hline G0012 & Kulit keriput \\
\hline G0013 & Perut cekung \\
\hline G0014 & Wajah seperti orang tua \\
\hline G0015 & Mata kemerahan \\
\hline G0016 & Mata berair \\
\hline G0017 & Mata terasa gatal \\
\hline G0018 & Mata sembab \\
\hline G0019 & Sensitif terhadap cahaya \\
\hline G0020 & Batuk berdahak \\
\hline G0021 & Hidung tersumbat \\
\hline G0022 & Panas dingin \\
\hline G0023 & Pilek \\
\hline G0024 & Batuk \\
\hline G0025 & Bersin-bersin \\
\hline G0026 & Sakit tenggorokan \\
\hline G0027 & Sakit kepala \\
\hline G0028 & Sesak nafas \\
\hline G0029 & Nafas cepat \\
\hline G0030 & Detak jantung cepat \\
\hline G0031 & Nafas berbunyi \\
\hline G0032 & Nyeri ulu hati \\
\hline G0033 & Perut kembung \\
\hline & \\
\hline
\end{tabular}




\begin{tabular}{|l|l|}
\hline G0034 & Hilang hafsu makan \\
\hline G0035 & Cepat kenyang saat makan \\
\hline G0036 & Gatal-gatal \\
\hline G0037 & Kulit memerah atau ruam \\
\hline G0038 & Bengkak pada wajah \\
\hline G0039 & Bintik kemerahan \\
\hline G0040 & Benjolan pada kulit \\
\hline G0041 & Ruam \\
\hline G0042 & Kulit kering bersisik \\
\hline G0043 & Perubahan warna kulit \\
\hline G0044 & Hilang kesadaran \\
\hline G0045 & Berkeringat \\
\hline G0046 & Tangan dan kaki kejang \\
\hline G0047 & Terkadang keluar busa dari mulut \\
\hline G0048 & Nyeri perut \\
\hline G0049 & Gangguan pencernaan \\
\hline G0050 & Dehidrasi \\
\hline G0051 & Mendadak demam tinggi \\
\hline G0052 & Sakit dibelakang mata \\
\hline G0053 & Sakit kepala yang hebat \\
\hline G0054 & Ruam di bagian tubuh \\
\hline G0055 & Kulit mudah memar \\
\hline G0056 & Muncul rasa nyeri \\
\hline G0057 & Rasa terbakar pada tempat infeksi \\
\hline G0058 & Lesi kulit (seperti melepuh) \\
\hline G0059 & Lemas \\
\hline G0060 & Benjolan merah atau merah muda \\
\hline G0061 & Benjolan lecet berisi cairan \\
\hline G0062 & Benjolan berkerak atau berkeropeng \\
\hline G0063 & Mata memerah \\
\hline G0064 & Batuk pilek \\
\hline G0065 & Bintik putih tampak di sepanjang garis mulut \\
\hline G0066 & Gatal hebat terutama di malam hari \\
\hline G0067 & Ruam seperti jerawat \\
\hline G0068 & Bersisik \\
\hline G0069 & Kulit lecet seperti melepuh \\
\hline G0070 & Luka goresan akibat di garuk \\
\hline & \\
\hline
\end{tabular}

Pada rancangan gejala dan penyakit dibawah menjelaskan tabel 3.1 dan 3.2 adalah rancangan gejala dan penyakit yang berisi Kode dan Penyakit yang akan diimplementasikan ke metode Certainty Factor dan Demster Shafer.

\subsection{Perhitungan $\mathrm{CF}$}

Contoh Kasus Penyakit Diare Dan Gastroenteritis. Proses 1

Pada proses pertama pengguna memasukan nilai mb 0.9 dan nilai md 0.05 gejala demam tinggi. Jika proses pertama maka mb lama dan md lama dikosongkan terlebih dahulu, seperti Tabel 3.3.

Tabel 3.3 Proses 1 Metode CF

\begin{tabular}{|l|l|r|r|}
\hline Penyakit 2 & & & \\
\hline P0002 & & & \\
\hline Gejala 1 & & \multicolumn{1}{|c|}{ MB } & \multicolumn{1}{c|}{ MD } \\
\hline & Feses cair & 0,9 & 0,05 \\
\hline & & & \\
\hline MB lama & Kosong & 0 & \\
\hline MD Lama & Kosong & 0 & \\
\hline MB Baru & MB & 0,9 & \\
\hline
\end{tabular}

\begin{tabular}{|l|l|c|l|} 
MD Baru & MD & 0,05 & \\
\hline MB & & & \\
Sementara & MB Baru & 0,9 & \\
\hline MD & & & \\
Sementara & MD Baru & 0,05 & \\
\hline
\end{tabular}

\section{Proses 2}

Pada proses 2 pengguna memasukan nilai mb 0.9 dan md 0.05 dari gejala selanjutnya yaitu diare. Pada proses ini mb lama dan mo lama diambil dari nilai mb dan md gejala sebelumya pada proses 1 , lalu mencari nilai $\mathrm{mb}$ dan md sementara dengan rumus MB Lama + (MB Baru * (1 - MB Lama) dan MD Lama + (MD Baru* (1 - MD Lama) seperti pada Tabel 3.4.

Tabel 3.4 Proses 2 Metode CF

\begin{tabular}{|l|l|r|r|}
\hline Penyakit 2 & & & \\
\hline P0002 & & MB & MD \\
\hline Gejala 2 & & 0,6 & 0,1 \\
\hline & Mual dan muntah & & \\
\hline & & 0,9 & \\
\hline MB lama & MB Sementara & 0,05 & \\
\hline MD Lama & MD Sementara & 0,6 & \\
\hline MB Baru & MB & 0,1 & \\
\hline MD Baru & MD & & \\
MB & MB Lama + (MB & & \\
Sementara & $\begin{array}{l}\text { Baru } *(1-\text { MB } \\
\text { Lama) }\end{array}$ & 0,96 & \\
\hline $\begin{array}{l}\text { MD } \\
\text { Sementara }\end{array}$ & $\begin{array}{l}\text { MD Lama + (MD } \\
\text { Lama) }(1-\text { MD }\end{array}$ & & \\
\hline
\end{tabular}

\section{Proses 3}

Pada proses 3 pengguna memasukan nilai mb 0.6 dan md 0.1 dari gejala selanjutnya yaitu terlihat lemah atau lemas. Pada proses ini mb lama dan md lama diambil dari nilai mb dan md gejala sebelumya pada proses 2, lalu mencari nilai $\mathrm{mb}$ dan $\mathrm{md}$ sementara dengan rumus MB Lama + (MB Baru * (1 - MB Lama) dan MD Lama + (MD Baru* (1 - MD Lama) seperti pada Tabel 3.5.

Tabel 3.5 Proses 3 Metode CF

\begin{tabular}{|l|l|r|r|}
\hline Gejala 3 & & MB & MD \\
\hline & Sakit Perut & 0,7 & 0,2 \\
\hline & & & \\
\hline MB lama & MB Sementara & 0,96 & \\
\hline MD Lama & MD Sementara & 0,145 & \\
\hline MB Baru & MB & 0,7 & \\
\hline MD Baru & MD & 0,2 & \\
\hline MB & MB Lama + (MB & & \\
Sementara & Baru * (1 - MB & 0,988 & \\
\hline $\begin{array}{l}\text { MD } \\
\text { Sementara }\end{array}$ & $\begin{array}{l}\text { MD Lama + (MD } \\
\text { Baru * (1 - MD }\end{array}$ & & \\
Lama) & 0,316 & \\
\hline
\end{tabular}

\section{Proses 4}

Pada proses 4 pengguna memasukan nilai mb 0.7 dan md 0.2 dari gejala sembelit. Pada proses ini 
mb lama dan md lama diambil dari nilai mb dan md gejala sebelumya pada proses 3 , lalu mencari nilai $\mathrm{mb}$ dan md sementara dengan rumus MB Lama + (MB Baru * (1 - MB Lama) dan MD Lama + (MD Baru* (1 - MD Lama) seperti pada Tabel 3.6.

Tabel 3.6 proses 4 Metode CF

\begin{tabular}{|c|c|c|c|}
\hline Penyakit 2 & & & \\
\hline P0002 & & & \\
\hline Gejala 4 & & MB & MD \\
\hline & $\begin{array}{l}\text { Kehilangan } \\
\text { nafsu makan }\end{array}$ & 0,6 & 0,2 \\
\hline MB lama & MB Sementara & 0,988 & \\
\hline MD Lama & MD Sementara & 0,316 & \\
\hline MB Baru & MB & 0,6 & \\
\hline MD Baru & $\mathrm{MD}$ & 0,2 & \\
\hline $\begin{array}{l}\text { MB } \\
\text { Sementara }\end{array}$ & $\begin{array}{l}\text { MB Lama + } \\
(\text { MB Baru * }(1 \\
\text { - MB Lama) }\end{array}$ & 0,9952 & \\
\hline $\begin{array}{l}\text { MD } \\
\text { Sementara }\end{array}$ & $\begin{array}{l}\text { MD Lama }+ \\
(\text { MD Baru * }(1 \\
- \text { MD Lama) }\end{array}$ & 0,4528 & \\
\hline
\end{tabular}

\section{Proses 5}

Pada proses 5 pengguna memasukan nilai mb 0.7 dan md 0.2 dari gejala kehilangan nafsu makan. Pada proses ini mb lama dan md lama diambil dari nilai mb dan md gejala sebelumya pada proses 4 , lalu mencari nilai $\mathrm{mb}$ dan md sementara dengan rumus MB Lama + (MB Baru * (1 - MB Lama) dan MD Lama + (MD Baru* (1 - MD Lama) seperti pada Tabel 3.7.

Tabel 3.7 proses 5 Metode CF

\begin{tabular}{|l|l|r|r|}
\hline Penyakit 2 & & & \\
\hline P0002 & & & \\
\hline Gejala 5 & & & \\
\hline & Demam & 0,6 & 0,2 \\
\hline & & & \\
MB lama & $\begin{array}{l}\text { MB } \\
\text { Sementara }\end{array}$ & 0,9952 & \\
\hline MD Lama & $\begin{array}{l}\text { MD } \\
\text { Sementara }\end{array}$ & 0,4528 & \\
\hline MB Baru & MB & 0,6 & \\
\hline MD Baru & MD & 0,2 & \\
\hline & $\begin{array}{l}\text { MB Lama }+ \\
\text { (MB Baru * }\end{array}$ & & \\
MB & $(1-$ MB & & \\
Sementara & Lama) $)$ & 0,99808 & \\
\hline & $\begin{array}{l}\text { MD Lama }+ \\
\text { (MD Baru * }\end{array}$ & & \\
MD & $(1-$ MD & & \\
Sementara & Lama) & 0,56224 & \\
\hline & $\begin{array}{l}\text { MB } \\
\text { Sementara - }\end{array}$ & & \\
& MD & & \\
Hasil CF & Sementara & 0,43584 & \\
\hline
\end{tabular}

Perbandingan Perhitungan Manual Dan Sistem seperti pada Tabel

Hasil

$\mathrm{Cf}=\mathrm{MB}$ Sementara - Md Sementara $=0.43584$

\subsection{Perhitungan DS}

Perhitungan pada kode gejala G0001, G0002, G0003, G0004, dan G0005

\section{Proses 1}

Memilih 5 gejala pada penyakit balita, yaitu mata berair, batuk berdahak, panas dingin, demam, dan sesak nafas, langkah pertama menghitung gejala mata berair dengan batuk berdahak, dan dihasilkan tabel 3.8.

Tabel 3.8 Proses 1 pada metode Demster shafer.

\begin{tabular}{|c|c|c|c|c|c|}
\hline & & $\begin{array}{l}\text { P0001, } \\
\text { P0012, } \\
\text { P0019 }\end{array}$ & 0,5 & $\varnothing$ & 0,5 \\
\hline $\begin{array}{l}\text { P0001, } \\
\text { P0011 }\end{array}$ & 0,7 & P0001 & 0,35 & $\begin{array}{l}\text { P0001, } \\
\text { P0011 }\end{array}$ & 0,35 \\
\hline$\emptyset$ & 0,3 & $\begin{array}{l}\text { P0001, } \\
\text { P0012, } \\
\text { P0019 }\end{array}$ & 0,15 & $\varnothing$ & 0,15 \\
\hline
\end{tabular}

Pada tabel 3.9 merupakan hasil dari pengelompokan kode penyakit dan hasil perhitungannya yang di ambil dari tabel 3.8, untuk mendapakan nilai theta dengan cara 1- nilai bobot, dan untuk nilai yang didapatkan pada kode penyakit dengan cara mengalikan dengan nilai bobot dengan nilai bobot baru dan dengan nilai theta.

Tabel 3.9 Hasil Proses 1 pada metode Demster shafer.

\begin{tabular}{|l|r|}
\hline P0001 & 0,35 \\
\hline P0001,P0012,P0019 & 0,15 \\
\hline P0001,P0011 & 0,35 \\
\hline$\varnothing$ & 0,15 \\
\hline
\end{tabular}

Proses 2

Tabel 3.10 Proses 2 pada metode Demster shafer

\begin{tabular}{|l|r|l|r|l|r|}
\hline & & P0001 & 0,3 & $\emptyset$ & 0,7 \\
\hline P0001 & 0,35 & P0001 & 0,105 & P0001 & 0,245 \\
\hline P0001, & & & & P0001, & \\
P0012, & & & & P0012, & \\
P0019 & 0,15 & P0001 & 0,045 & P0019 & 0,105 \\
\hline P0001, & & & & P0001, & \\
P0011 & 0,35 & P0001 & 0,105 & P0011 & 0,245 \\
\hline$\varnothing$ & 0,15 & P0001 & 0,045 & $\varnothing$ & 0,105 \\
\hline
\end{tabular}

Pada tabel 3.11 merupakan hasil dari pengelompokan kode penyakit dan hasil perhitungannya yang di ambil dari tabel 3.10, untuk mendapakan nilai theta dengan cara 1 - nilai bobot, dan untuk nilai yang didapatkan pada kode penyakit dengan cara mengalikan dengan nilai bobot dengan nilai bobot baru dan dengan nilai theta.

Tabel 3.11 Hasil Proses 2 pada metode Demster shafer.

\begin{tabular}{|l|l|}
\hline P0001 & 0,545 \\
\hline P0001,P0012,P0019 & 0,105 \\
\hline P0001,P0011 & 0,245 \\
\hline$\varnothing$ & 0,105 \\
\hline
\end{tabular}




\section{Proses 3}

Table 3.12 Proses 3 pada metode Demster shafer.

\begin{tabular}{|l|r|l|r|l|r|}
\hline & & P0001 & 0,2 & $\varnothing$ & 0,8 \\
\hline P0001 & 0,545 & P0001 & 0,109 & P0001 & 0,436 \\
\hline P0001, & & & & P0001, & \\
P0012, & & & & P0012, & \\
P0019 & 0,105 & P0001 & 0,021 & P0019 & 0,084 \\
\hline P0001, & & & & P0001, & \\
P0011 & 0,245 & P0001 & 0,049 & P0011 & 0,196 \\
\hline$\varnothing$ & 0,105 & P0001 & 0,021 & $\varnothing$ & 0,084 \\
\hline
\end{tabular}

Pada tabel 3.13 merupakan hasil dari pengelompokan kode penyakit dan hasil perhitungannya yang di ambil dari tabel 3.12, untuk mendapakan nilai theta dengan cara 1 - nilai bobot, dan untuk nilai yang didapatkan pada kode penyakit dengan cara mengalikan dengan nilai bobot dengan nilai bobot baru dan dengan nilai theta.

Table 3.13 Hasil Proses 3 pada metode Demster shafer.

\begin{tabular}{|l|l|}
\hline P0001 & 0,636 \\
\hline P0001,P0012,P0019 & 0,084 \\
\hline P0001,P0011 & 0,196 \\
\hline$\varnothing$ & 0,084 \\
\hline
\end{tabular}

\section{Proses 4}

Tabel 3.14 Proses 4 pada metode Demster shafer.

\begin{tabular}{|c|c|c|c|c|c|}
\hline & & $\begin{array}{l}\text { P0001, } \\
\text { P0002 }\end{array}$ & 0,4 & $\varnothing$ & 0,6 \\
\hline P0001 & 0,64 & P0001 & 0,25 & P0001 & 0,38 \\
\hline $\begin{array}{l}\text { P0001, } \\
\text { P0012, } \\
\text { P0019 }\end{array}$ & 0,08 & P0001 & 0,03 & $\begin{array}{l}\text { P0001, } \\
\text { P0012, } \\
\text { P0019 }\end{array}$ & 0,05 \\
\hline $\begin{array}{l}\text { P0001, } \\
\text { P0011 }\end{array}$ & 0,19 & P0001 & 0,08 & $\begin{array}{l}\text { P0001, } \\
\text { P0011 }\end{array}$ & 0,12 \\
\hline$\varnothing$ & 0,08 & $\begin{array}{l}\text { P0001, } \\
\text { P0002 }\end{array}$ & 0,03 & $\varnothing$ & 0,05 \\
\hline
\end{tabular}

Pada tabel 3.15 merupakan hasil dari pengelompokan kode penyakit dan hasil perhitungannya yang di ambil dari tabel 3.14, untuk mendapakan nilai theta dengan cara 1- nilai bobot, dan untuk nilai yang didapatkan pada kode penyakit dengan cara mengalikan dengan nilai bobot dengan nilai bobot baru dan dengan nilai theta.

Tabel 3.15 Hasil Proses 4 pada metode Demster shafer.

\begin{tabular}{|l|r|}
\hline P0001 & 0,748 \\
\hline P0001,P0002 & 0,0336 \\
\hline P0001,P0012,P0019 & 0,0504 \\
\hline P0001,P0011 & 0,1176 \\
\hline$\varnothing$ & 0,0504 \\
\hline
\end{tabular}

Hasil dari metode Demster Shafer dapat disimpulkan kemungkinan terbesar menderita penyakit pada kode penyakit P0001 sebesar 0,748= $74,8 \%$. Pada kode P0001 pasien menderita penyakit dengan nama Demam Typhoid dan Paratyphoid (Panas tipes).

\subsection{Sturktur Menu}

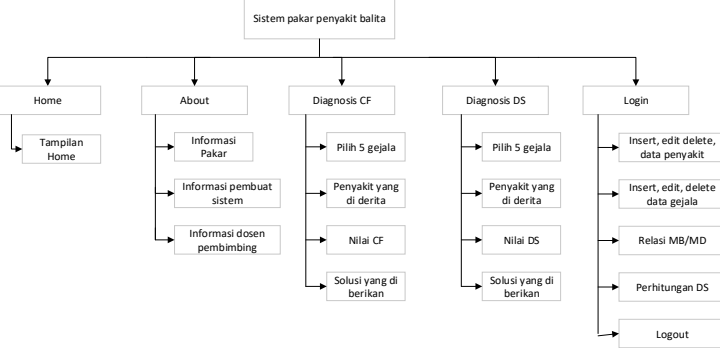

Gambar 3.1 Struktur menu

Gambar 3.1 struktur yang dapat dilakukkan pada user dan admin, pada menu user, user dapat melihat about, diagnosis pada metode $\mathrm{CF}$ dan diagnosis pada metode DS sedangkan pada halaman login atau halaman admin, admin bisa melakukan insert, edit, dan delete pada data penyakit, gejala, relasi MB/MD dan perhitungan DS.

\subsection{Flowchard User}

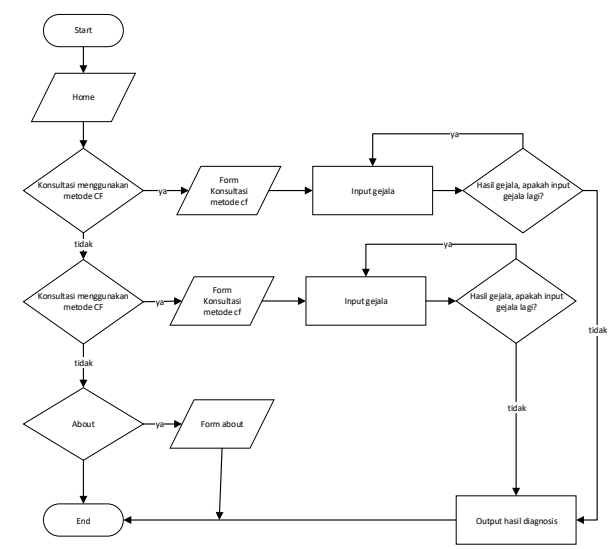

Gambar 3.2 Flowchart user

Gambar 3.2 Sistem ini dimulai dengan halaman home user yang berisi deskripsi sistem pakar, halaman konsultasi pakar berisi form diagnosis yang nanti nya user akan memilih gejala yang sudah ada lalu akan di proses oleh sistem sesuai dengan aturan yang sudah dibuat, kemudian dilanjutkan proses Certainty Factor Setelah proses selesai maka akan muncul informasi hasil diagnosis berupa penyakit dan saran. Selanjutnya dihalaman berikut ada halaman kontak yang berisi tentang info kontak admin.

\subsection{Flowchart CF}

Gambar 3.3 merupakan flowchart perhitungan dari progam sistem pakar penjelasan sebagai berikut. Pertama mulai diagnosis dan memasukan nilai gejala, jika gejala berjumlah satu maka proses perhitungan yaitu $\mathrm{CF}=\mathrm{MB}-\mathrm{MD}$ maka nilai md dari gejala tersebut dikurangi md gejala tersebut. Jika jumlah 
gejala berjumlah 2 maka proses perhitunganya adalah Mb Lama + (Mb Baru*(1-Mb-lama) dan sebaliknya. Maka jika jumlah gejala 2 nilai mb sebelumya ditambah b baru yang gejala kedua di kalikan 1 dikurangi mb lama begitu juga sebaliknya untuk nilai md. Jumlah gejala lebh dari tiga maka proses perhitungan sebagai berikut, $\mathrm{Mb}$ Lama $+(\mathrm{Mb}$ Baru*(1-Mb-lama). Maka jika jumlah gejala lebih dari tiga atau sama dengan tiga maka mb baru / nilai gejala sebelumya di kali 1 dikurangi mb yang lama. Dan seterusnya. Jika sudah memenuhi sampai gejala yan terahir maka nilai $\mathrm{Cf}=\mathrm{Mb}-\mathrm{Md}$ dan hasilnya akan menjadi nilai Certainy Factor penyakit.

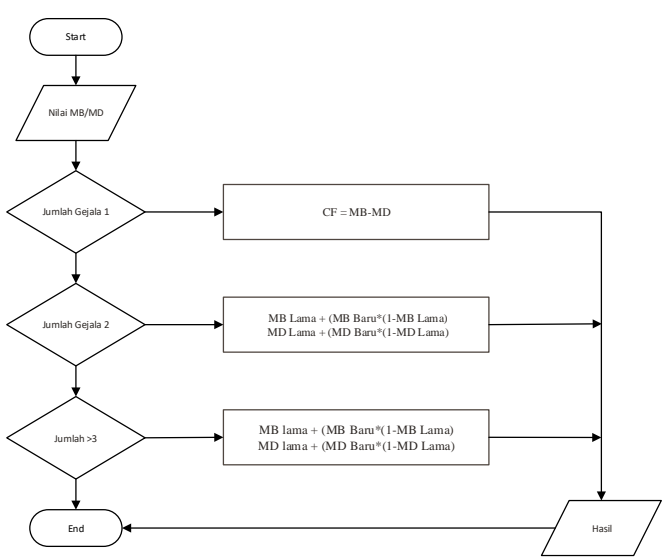

Gambar 3.3 flowchart Certainty Factor

\subsection{Flowchart DS}

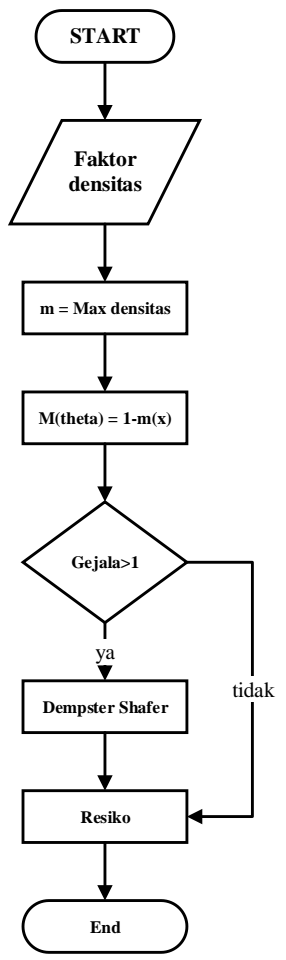

Gambar 3.4 flowchart Dempster Shafer
Gambar 3.4 Mrupakan flowchat Dempster Shafer, dimulai dengan memasukkan nilai densitas tiap faktor resiko ke dalam basisdata sebagai dasar perhitungan. Kemudian pengguna memasukkan faktor-faktor resiko yang telah dialami kedalam aplikasi sistem pakar yang dibuat. Apabila masih terdapat masukkan baru, akan dilakukan proses perhitungan nilai densitas baru dengan menggabungkan antara nilai densitas ketiga dengan nilai densitas masukkan berikutnya. Proses akan terus berulang sebanyak masukkan yang dilakukan oleh pengguna. Apabila semua resiko sudah selesai dihitung, maka kesimpulan akan diperoleh dari hasil nilai densitas gabungan yang paling terakhir dihitung.

\section{PENGUJIAN}

\subsection{Pengujian fungsional}

Pengujian sistem merupakan proses menampilkan sistem dengan maksud untuk menemukan adanya kesalahan atau tidak pada sistem sebelum sistem dipublikasikan untuk digunakan oleh masyarakat. Penggujian dilakukan dengan menggunakan browser Mozilla dan google chrome.

Table 4.1 Table Pengujian bowser.

\begin{tabular}{|c|c|c|c|}
\hline \multirow[b]{2}{*}{ Akses } & \multirow[b]{2}{*}{ Fungsi } & \multicolumn{2}{|c|}{ Browser } \\
\hline & & Mozilla & $\begin{array}{l}\text { Google } \\
\text { Chrome }\end{array}$ \\
\hline \multirow{4}{*}{ Admin } & $\begin{array}{l}\text { Bisa mengakses halaman } \\
\text { admin untuk login. }\end{array}$ & $\checkmark$ & $\checkmark$ \\
\hline & $\begin{array}{l}\text { Dapat melakukan tambah, } \\
\text { edit, dan hapus data } \\
\text { penyakit. }\end{array}$ & $\checkmark$ & $\checkmark$ \\
\hline & $\begin{array}{l}\text { Dapat melakukan tambah, } \\
\text { edit, dan hapus data gejala. }\end{array}$ & $\checkmark$ & $\checkmark$ \\
\hline & $\begin{array}{l}\text { Dapat melakukan tambah, } \\
\text { edit, dan hapus data relasi . }\end{array}$ & $\checkmark$ & $\checkmark$ \\
\hline \multirow{3}{*}{ User } & $\begin{array}{l}\text { Dapat melihat menu home } \\
\text { user. }\end{array}$ & $\checkmark$ & $\checkmark$ \\
\hline & $\begin{array}{l}\text { Dapat melakukan proses } \\
\text { diagnosis konsultasi pakar } \\
\text { pada metode CF saja. }\end{array}$ & $\checkmark$ & $\checkmark$ \\
\hline & Dapat melihat menu tentang & $\checkmark$ & $\checkmark$ \\
\hline
\end{tabular}

\subsection{Pengujian pada excel dan sistem metode $\mathbf{C F}$}

Tabel 4.2 Pengujian error pada metode Certainty

\begin{tabular}{|c|r|r|r|}
\multicolumn{5}{c}{ Factor. } \\
$\begin{array}{c}\text { Kode } \\
\text { Penyakit }\end{array}$ & $\begin{array}{c}\text { Perhitungan } \\
\text { manual }\end{array}$ & $\begin{array}{c}\text { Pada } \\
\text { sistem }\end{array}$ & $\begin{array}{c}\text { Hasil dan } \\
\text { selisih }\end{array}$ \\
\hline P0001 & 0,27744 & 0,21232 & 0,06512 \\
\hline P0002 & 0,43584 & 0,43008 & 0,00576 \\
\hline P0003 & 0,38232 & 0,38232 & 0 \\
\hline P0004 & 0,40536 & 0,40536 & 0 \\
\hline P0005 & 0,52272 & 0,46464 & 0,05808 \\
\hline P0006 & 0,4104 & 0,39888 & 0,01152 \\
\hline P0007 & 0,622815 & 0,61917 & 0,003645 \\
\hline P0008 & 0,52104 & 0,51456 & 0,00648 \\
\hline P0009 & 0,4518 & 0,4518 & 0 \\
\hline P0010 & 0,45783 & 0,45783 & 0 \\
\hline
\end{tabular}


Pada penelitian sistem yang dilakukan untuk menguji keakuratan perhitungan sistem dan analisis perhitungan manual didapatkan presentasi error sebesar $0.150605 \%$.

\subsection{Pengujian pada excel dan sistem metode DS}

Tabel 4.3 Pengujian pada metode Demster Shafer

\begin{tabular}{|l|r|r|r|}
\hline \multicolumn{1}{|c|}{ Kode Gejala } & Perhitungan manual & Pada sistem & Hasil dan selisih \\
\hline G0001,G0002,G0003,G0004,G0005 & 0,748 & 0,748 & 0 \\
\hline G0005,G0006, G0007,G0008, G0009 & 0,955 & 0,955 & 0 \\
\hline G00010,G0011, G0012,G0013, G0014 & 0,988 & 0,988 & 0 \\
\hline G0015,G0016, G0017,G0018, G0019 & 0,958 & 0,958 & 0 \\
\hline G0016,G0020, G0021,G0022, G0023 & 0,912 & 0,912 & 0 \\
\hline G0021,G0024, G0025,G0026, G0027 & 0,855 & 0,855 & 0 \\
\hline G0020,G0028, G0029,G0030, G0031 & 0,973 & 0,973 & 0 \\
\hline G0007,G0032, G0033,G0034, G0035 & 0,964 & 0,964 & 0 \\
\hline G0036,G0037, G0038, G0039 & 0,825 & 0,825 & 0 \\
\hline G0036,G0040, G0041,G0042, G0043 & 0,94288 & 0,94288 & 0 \\
\hline
\end{tabular}

Pada penelitian sistem yang dilakukan untuk menguji keakuratan perhitungan sistem dan analisis perhitungan manual didapatkan presentasi error sebesar $0 \%$.

\subsection{Halaman Administrator Sistem Pakar}

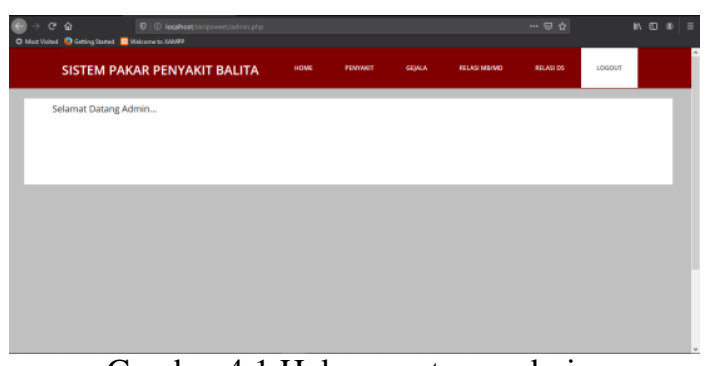

Gambar 4.1 Halaman utama admin.

Gambar 4.1 merupakan halaman utama pada admin yang berisi gejala penyakit relasi dan tentang dan dapat mengganti atau menambah data dari pakar.

\subsection{Halaman Penyakit Pada Admin}

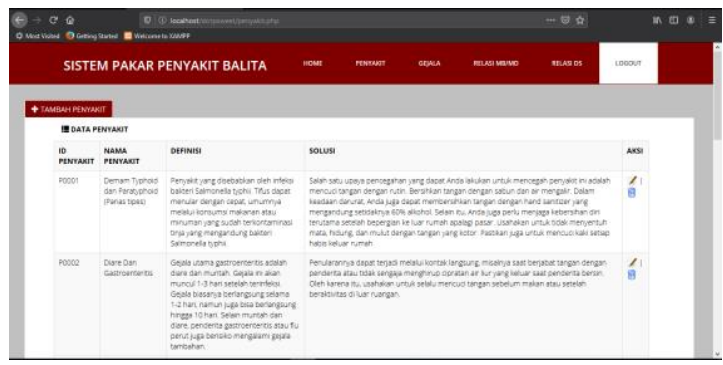

Gambar 4.2 Halaman Penyakit Pada Admin
Gambar 4.2 merupakan tampilan halaman penyakit pada admin yang berisis edit penyakit, tambah penyakit dan hapus penyakit.

\subsection{Halaman Gejala Pada Admin}

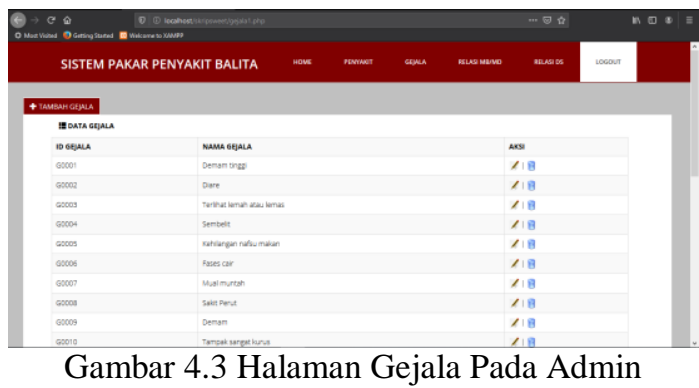

Gambar 4.3 Merupakan halaman gejala pada admin yang berisi edit gejala, tambah gejala dan hapus gejala.

\subsection{Halaman Diagnosis Certainty Factor.}

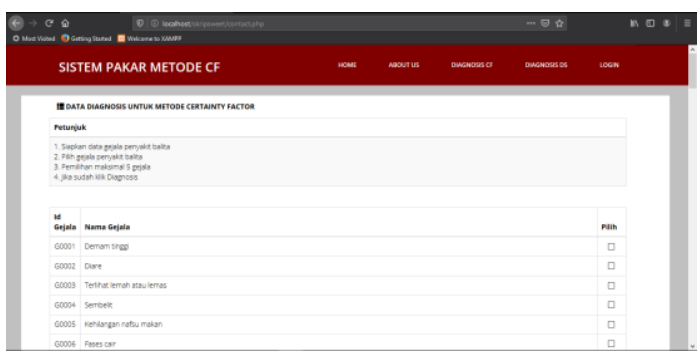

Gambar 4.4 Halaman Diagnosis Certainty Factor

Gambar 4.12 merupakan tampilan diagnosis penyakit yang berisi gejala untuk menentukan suatu penyakit yang diderita. 


\subsection{Halaman Hasil Diagnosis Certainty Factor.}

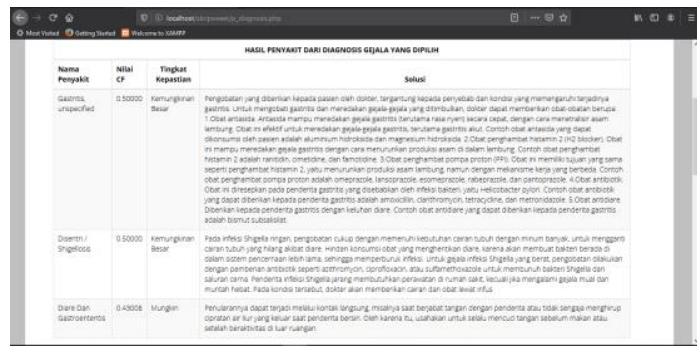

Gambar 4.13 Halaman Hasil Diagnosis Certainty Factor

Gambar 4.13 Merupakan Tampilan hasil diagnose dari gejala yang telah dipilih oleh user yang berisi nama penyakit, cf, definisi penyakit dan solusi penyakit. Penyakit dengan nilai Certainty Factor tertinggi adalah penyakit yang kemungkinan diderita oleh user.

\subsection{Halaman Diagnosis Demster Shafer.}

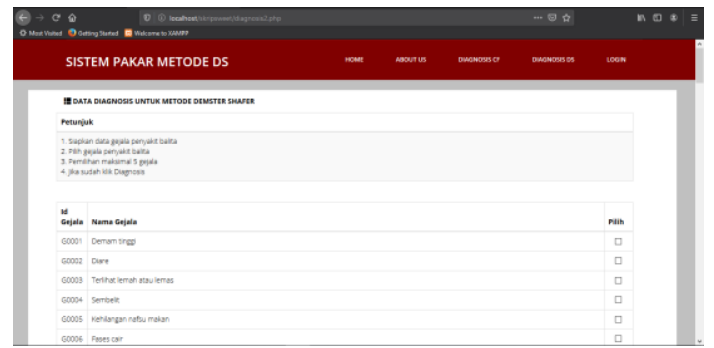

Gambar 4.14 Halaman Diagnosis Demster Shafer

Gambar 4.14 merupakan tampilan diagnosis penyakit yang berisi gejala untuk menentukan suatu penyakit yang diderita.

\subsection{Halaman Hasil Diagnosis Demster Shafer}

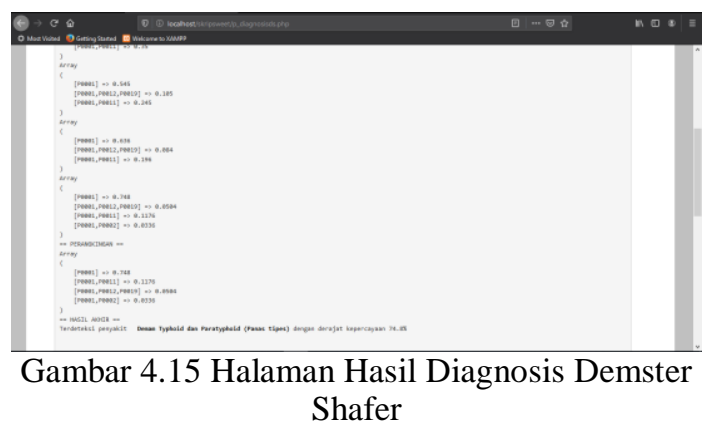

Gambar 4.15 Merupakan Tampilan hasil diagnose dari gejala yang telah dipilih oleh user yang berisi kode penyakit apa saya yang menyinggung pada gejala yang dipilih. Penyakit dengan nilai tertinggi adalah penyakit yang kemungkinan diderita oleh user.

\section{KESIMPULAN DAN SARAN}

\subsection{Kesimpulan}

Berdasarkan hasil dari perancangan dan implementasi dari penelitian sistem pakar diagnosis penyakit pencernaan menggunakan metode Certainty Factor maka dapat diambil beberapa kesimpulan yaitu :

1. Berdasarkan dari pengujian fungsionalitas sistem pakar diagnosis penyakit balita masih ada kendalan dari nalai $\mathrm{CF}$.

2. Berdasarkan hasil dari pengujian pembangunan sistem pakar diagnosis penyakit balita yang menggunakan metode Certainty Factor hampir sesuai dengan perhitungan manual.

3. Nilai pada metode Demster shafer lebih akurat dibandingkan metode Certainty Factor.

\subsection{Saran}

Agar dalam penelitian ini berjalan dengan baik kedepanya, maka ada beberapa hal yang perlu dilakukan yaitu sebagai berikut :

1. Tampilan akan diperbagus sehingga pengguna akan lebih nyaman menggunakan sistem pakar ini.

2. Menambahkan pengetahuan akan beberapa penyakit pencernaan.

3. Keakuratan nilai ditingkatkan lagi.

\section{DAFTAR PUSTAKA}

[1] Putra, Rahmad, 2015, Analisa perbandingan metode Certainty Factor dan Demster Shafer pada sistem pakar diagnosa penyakit diabetes melimus. Jurnal Teknologi Informasi, Politeknik Negeri Malang, ISSN:2407-070X.

[2] Hamidi R, Anra Henky, Pratiwi Helen. 2017, Analisis Perbandingan Sistem Pakar dengan Metode Certainty Factor dan Metode DempsterShafer pada Penyakit Kelinci, Jurnal Sistem dan Teknologi Informasi (JUSTIN) Vol. 5, No. 2.

[3] Putra P. 2017, Sistem Pakar Diagnosa Penyakit ISPA (Infeksi Saluran Pernafasan Akut) Menggunakan Metode Certainty Factor Berbasis Web, Jati (Jurnal Mahasiswa Teknik Informatika), Vol. 1 No. 1, Maret 2017.

[4] M. Yusuf. 2017, Sistem Pakar Penyakit Leukemia Menggunakan Demster Shafer Berbasis Android, Jati (Jurnal Mahasiswa Teknik Informatika), Vol. 1 No. 1, Maret 2017.

[5] Orisa M. 2016, Aplikasi Sistem Pakar Diagnosis Penyakit Tebu Menggunakan Metode Certainty Factor Berbasis Web, Seminar Nasional Inovasi dan Aplikasi Teknologi Di Industri (SENIATI) 2016, ISSN : 2085-4218.

[6] Ani Andrian, 2016, Pemograman sistem pakar konsep dasar dan aplikasinya menggunakan VB 6, penerbit Mediakom.

[7] Hamidi R, Anra Henky, Pratiwi Helen. 2017, Analisis Perbandingan Sistem Pakar dengan Metode Certainty Factor dan Metode Dempster- 
Shafer pada Penyakit Kelinci, Jurnal Sistem dan Teknologi Informasi (JUSTIN) Vol. 5, No. 2.

[8] Ani Andrian, 2016, Pemograman sistem pakar konsep dasar dan aplikasinya menggunakan VB 6, penerbit Mediakom.

[9] Putra P. 2017, Sistem Pakar Diagnosa Penyakit ISPA (Infeksi Saluran Pernafasan Akut) Menggunakan Metode Certainty Factor Berbasis Web, Jati (Jurnal Mahasiswa Teknik Informatika), Vol. 1 No. 1, Maret 2017.

[10] Wibowo A.S., Rokhman M.M., Pranoto A.Y., 2019, Aplikasi Pemetaan Berbasis Website untuk Pusat Kesehatan Masyarakat di Wilayah Kabupaten Malang, Aplikasi Pemetaan Berbasis Website Suryo|Moh Miftakhur|Yosep, Vol. 2 No. 2 (2019): Mnemonic Vol. 2 No. 2.

[11] Auliasari K., Susanti Y., 2016, Analisis Keterkaitan Penyakit Pasien pada Puskesmas Menggunakan Metode Association Rule, Informatics Journal, ISSN : 2503 - 250X, Vol. 1 No. 2 (2016).
[12] Rifai R.Y.A., 2019, Penentuan Bibit Unggul Durian Menggunakan Metode Analythical Hierarky Process (AHP) Berbasis Web di Trenggalek, Jati (Jurnal Mahasiswa Teknik Informatika), Vol. 3 No. 2 September 2019.

[13] Prahita R, Widiartha KBI, Zubaid A. 2017, Sistem Informasi Perhotelan Berbasis Web Service : Studi Kasus di Pulau Lombok, JCOSINE, Vol. 1, No. 1, Desember 2017, EISSN:2541-0806, P-ISSN:2540-8895.

[14] Constantianus F, Suteja RB. 2005, Analisa dan Desain Sistem Bimbingan Tugas Akhir Berbasis Web dengan Studi Kasus Fakultas Teknologi Informasi, Jurnal Informatika UKM, Vol. 1, No. 2, Desember 2005: 93 - 106.

[15] Putra P. 2017, Sistem Pakar Diagnosa Penyakit ISPA (Infeksi Saluran Pernafasan Akut) Menggunakan Metode Certainty Factor Berbasis Web, Jati (Jurnal Mahasiswa Teknik Informatika), Vol. 1 No. 1, Maret 2017. 